\section{The distribution of coliform bacteria in waste water}

\author{
Dau Lal Bohra, Vikas Modasiya, \\ Chandan Kumar Bahura
}

Microbiological Section, Post Graduate

Department of Zoology, Government

Dungar College, Bikaner, Rajasthan, India

\begin{abstract}
Biological activity of water can be apparently judged by the colonization of bacteria (microbes). In order to find out the extent of pollution and the relationship between inorganic matters and microbiota, a quantitative and qualitative analysis of bacteria in various types of sewage waters, namely sewage water by the residential colonies (group I), industrial waste water (group II), sewage treatment hub (group III), unorganized collected waste water (group IV) and old residential waste collection center (group V), of Bikaner city (Rajasthan, India) was carried out from February, 2010 to May, 2010. Water samples were taken from surface only owing to low depth and investigated for various abiotic factors (viz. transparency, $\mathrm{pH}$, carbonate, bicarbonate, total alkalinity, total hardness, salinity, chloride, calcium, magnesium, sulphate, nitrate, silica, and inorganic phosphorous) and biotic factors (viz. number and diversity of bacteria). The domestic sewage water causes major water borne diseases basing upon Total Bacterial Count (TBC) and coliform Count (CC). The coliform count in the present study ranged from 2.5 to $5.12 \mathrm{MPN} / \mathrm{mL}$. Comparision of microbial population in sewage water from all different Groups was done and the higher values of TBC and $\mathrm{CC}$ were recorded only in Sewage treatement hub (Group III).
\end{abstract}

\section{Introduction}

The abundance and distribution of microorganisms in aquatic ecosystems result from a complex of environmental factors and trophic interactions among a multitude of biotic components. Water is synonymous to life as it is essential commodity for living beings including animals and plants, without which neither life nor development is possible. Domestic sewage is the major source of pollution of surface water in India which contributes pathogens, the main source of water borne diseases along with depletion of oxygen in water bodies. ${ }^{1,2}$ Sewage along with agricultural runoff and industrial effluents also contributes large amount of nutrients to surface water causing Eutrophication. ${ }^{2}$ Water microbiology is concerned with the microorganisms that live in water, or they can be transported from one habitat to another by water can support the growth of many types of microorganisms. ${ }^{3}$ However, the presence of other disease causing microbes in water is unhealthy and even life threatening. ${ }^{4,5}$ Bacteria found in the intestinal tracts of humans and other warm blooded animals, such as Escherichia coli, Salmonella, Shigella, and Vibrio spp. can contaminate water if feces enter the water supply.,6 Microbiological studies are of great importance both from the point of view of monitoring and maintaining a proper aquatic environment as well as optimum utilization of the available and added nutrient for fish production. ${ }^{5}$ The microbiological examination of water has significant importance in case of pollution studies.

The aquatic microorganism includes pathogenic bacteria which cause diseases such as typhoid, fever, dysentery, diarrhea and cholera etc. The presence of pathogens is indirectly detected by studying indicator organisms. ${ }^{2}$ The most common indicator organisms are a group of microbes called coliforms the presence of which simply indicates that pathogens are expected to be present.?

The term coliform refers to a group of bacteria that reside in the intestines of many vertebrates. It includes species such Eschirichia, Cirtobactor, Enterobactor and Klebsiella. ${ }^{8,7}$

Water quality monitoring facilitates evaluation of nature and extent of pollution and effectiveness of pollution control measures, water quality trends and prioritisation of pollution control efforts. So in order to find out the extent of pollution, a study was conducted to know the relationship between inorganic matter and distribution of genera and population of bacteria in various types of sewage waters.

\section{Materials and Methods}

The investigations of sewage of Bikaner city was carried out from February, 2010 to May, 2010 (4 month). The results are presented as average of four months (Table 1 and 2, Figure 1). The water samples were taken from the surface, as the depths were very low, during morning between 7.00 a.m. to 12.00 a.m., and were investigated for various abiotic and biotic factors. Among abiotic factor included essential physicochemical parameters viz. transparency, pH, carbonate, bicarbonate, total alkalinity, total hardness, salinity, chloride, calcium, magnesium, sulphate, nitrate, silica, and inorganic phosphorous. Biotic factors included number and diversity of bacteria.
Correspondence: Dau Lal Bohra, Micriobiological Section, Kabberi Changanio ki Gali, Battron Ka Chowk, Bikaner 334001, Rajasthan, India.

Tel: +91.926.954.4299.

E-mail: daulalbohara@yahoo.com

Key words: sewage, microbial population, bacteria, bikaner.

Acknowledgements: we are thankful to the Head, Department of Zoology, Government Dungar College for providing excellent facilities for this project.

Received for publication: 27 July 2011.

Revision received: 13 December 2011.

Accepted for publication: 14 December 2011.

This work is licensed under a Creative Commons Attribution NonCommercial 3.0 License (CC BYNC 3.0).

(C) Copyright D.L. Bohra et al., 2012

Licensee PAGEPress, Italy

Microbiology Research 2012; 3:e2

doi:10.4081/mr.2012.e2

Standard methods ${ }^{9,7}$ were followed for the monitoring of physical and chemical parameters. Bacteriological examination was done using standard procedure suggested by manual of APHA. ${ }^{3}$

\section{Result and Discussion}

In the present study major gram negative and Enterobacteriacae family bacteria occurred in sewage water including Klabsiella spp. Entreobacter spp., E. coli, Pasteurella spp, and Proteus spp. Other than Enterobacteriacae family, Salmonella spp., Naisseria spp. and NLF Unidentified Enterobacter, Gram negative bacteria are present.

The present study is divided into five groups (Table 1) Enterobacter and E. coli are significantly present in all the groups. Either of it and NLF Unidentified Enterobacter are present in Group I, II and III.

As compared in all the Groups higher prevalence of Gram's negative bacteria, comparatively in lower number, as follows- Group V> Group IV > Group III > Group I > Group II. The higher prevalence of Enterobacteriace occurs in only Group V. Klebsiella spp. is only present in single Group (V).

In general, the domestic sewage water causes major water borne diseases depending upon Total Bacterial Count (TBC) and Coliform Count (CC). In the present study, the coliform count in the present study ranged $2.5 \mathrm{MPN} / \mathrm{mL}$ to $5.12 \mathrm{MPN} / \mathrm{mL}$. We also compared microbial population in sewage water from all different 
Groups and we observed that higher value of TBC and CC only in Group III and lowest in Group V. TBC and CC are almost similar to Group IV and V respectively. (Table 2 and Figure 1)

Biological activity of water apparently judged by the colonization of bacteria development. ${ }^{10}$ The sewage generally contains many pathogenic microorganisms including vegetables and animal creatures too, as indicator of organisms for the characterisation of water and also suggested various bacteria for the individual saprobic stages. ${ }^{2,11}$ In present study major gram negative and Entero-bacteriacae family bacteria occurred in sewage water including enterobacter spp., Klabsiella spp. Entrobacter spp., E. coli, Pasteurella spp, and Proteus spp. Other than Enterobacte-riacae family, Naisseria spp. and NLF Unidentified Enterobacter, Gram negative bacteria are present.

Higher bacterial population was obviously due to addition of more sewage and fecal matters through greater human activities. ${ }^{11}$ The fluctuation in the number of bacteria in sewage may be attributed to the irregular influx of domestic and industrial effluent into sewage. ${ }^{12}$

In the present study the total bacterial count was reported to be ranging from 42.0 to $55 \times 10^{6}$ MPN/100 mL. Similarly in another study ${ }^{12}$ observed Coliform 8.00 to $920 \times 10^{7}$ MPN/100 $\mathrm{mL}, E$. coli 2.00 to $630 \times 10^{7} \mathrm{MPN} / 100 \mathrm{~mL}$, fecal streptococci 9.00 to $7700 \times 10^{3} \mathrm{MPN} / 100 \mathrm{~mL}$, Leptothrix sp. Nil to $42 \times 10^{5} \mathrm{MPN} / 100 \mathrm{~mL}$ and Zoogloea sp. nil to $22 \times 10^{5}$ no.s $/ 100 \mathrm{~mL}$ in sewage water of Aligarh. Coliform, E. coli and fecal streptococci from 14 to $224.6 \times 10^{6}$ MPN/100 mL, 8.9 to $47 \times 10^{6} \mathrm{MPN} / 100 \mathrm{~mL}$ respectively in sewage of Ahmedabad. ${ }^{13}$

Among the pond waters of Aligarh Kalidah, (which receives the sewage) contained more coliforms 200 to $490 \times 10^{5} \mathrm{MPN} / 100 \mathrm{~mL}, E$. coli 70 to $280 \times 10^{5} \mathrm{MPN} / 100 \mathrm{~mL}$, Faecal streptococci 230 to $490 \times 10^{2} \mathrm{MPN} / 100 \mathrm{~mL}$, Leptothrix sp. 253 to $630 \mathrm{nos} / 100 \mathrm{~mL}$ and Zoogloea sp. 112 to $280 \mathrm{nos} / 100 \mathrm{~mL}$. The fluctuation in the number of bacteria in sewage may be attributed to the irregular influx of domestic and industrial effluents into sewage. ${ }^{12}$

In the present study, bacterial counts were high. The bacteria can survive and reproduce more successfully under warm conditions ${ }^{6,14,15}$ due to free sediment water interactions and less available dilution in summer. ${ }^{5}$ Fecal bacterial indicators are known to have longer survival when in association with sediment particles. $^{12,14}$ The presences of species of bacteria related to waterborne diseases were moderate thereby indicating non-potable nature of the waters. ${ }^{5}$

\section{Conclusions}

Water is contaminated with human wastes which may carry disease germs and parasites. In urban areas they may use water in toilets to carry these wastes away. Animal wastes may also carry disease germs which can get into water and pollute it. These wastes not only carry diseases and other dangerous things, they also may be high in nitrogen nutrients. Too high a level of nutrients can make algae grow too fast in streams, lakes or lagoons, smothering other kinds of life and building up until they start to rot and kill the fish. If the nitrogen compounds get into drinking water, they can be turned into nitrites which have been linked to cancer in humans. Higher value of TBC and CC was noticed only in Sewage treatment hub (Group III) indicating more polluted than other types of water. The presences of species of bacteria related to waterborne diseases were moderate thereby indicating non-potable nature of the water.

\section{References}

1. Bilgrami KS, Bhowmick BN, Singh AK. Impact of abiotic factors on bacterial population of river Ganga. Proc Indian Nati Sci

Table 1. Occurrence of different species of bacteria from different sewage groups of Study area.

\begin{tabular}{lccccc} 
Bacteria & Group I & Group II & Group III & Group IV & Group V \\
Enterobacter spp. & + & + & + & + & + \\
Klebsiella spp. & + & - & - & + & + \\
\hline E. coli & + & + & + & + & + \\
Pasteurella spp. & + & - & + & - & - \\
\hline Proteus spp. & - & - & - & - & - \\
Salmonella spp. & + & + & + & + & - \\
Neisseria spp. & - & - & - & + & + \\
NLF Unidentified Enterobacter & + & - & + & + & + \\
\hline
\end{tabular}

Table 2. Microbial populations in the sewage water samples in different groups from Bikaner.

\begin{tabular}{lcc} 
Groups/Area & $\begin{array}{c}\text { Total bacterial Count } \\
\left(10^{6 /} / \mathrm{MPN} / \mathrm{mL}\right)\end{array}$ & $\begin{array}{c}\text { Coliform Count } \\
(\mathbf{1 0} / \mathrm{MPN} / \mathrm{mL})\end{array}$ \\
Group I (sewage water from residential colonies) & 47 & 3.40 \\
Group II (Industrial waste water) & 52 & 4.40 \\
\hline Group III (sewage treatment hub) & 55 & 5.12 \\
Group IV (unorganized collected waste water) & 42 & 2.90 \\
\hline Group V (old residential waste collection center) & 40 & 2.50
\end{tabular}

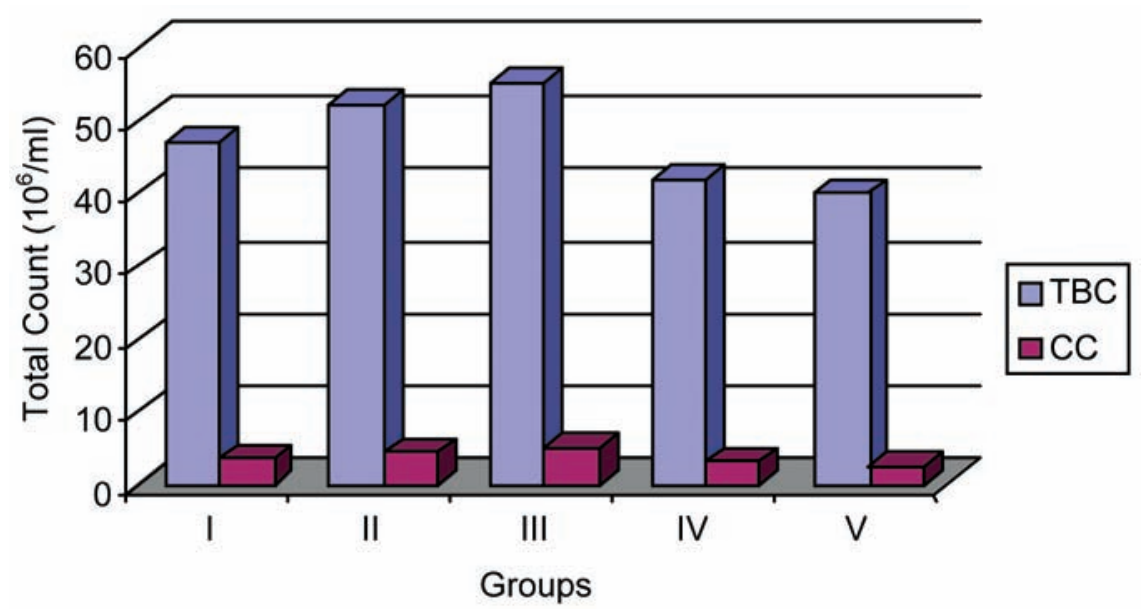

Figure 1. Microbial population in d ifferent water groups. 
Acad 1986;52:70-7.

2. Singh AK, Physico-chemical and bacterial study of sewage water discharged into the river Ganga at Bhagalpur, India. Environ Ecol 1985;3:138-42.

3. APHA. Standard methods for examination of water and wastewater. New York: American Public Health Association; 1989.

4. Geldreich EE. Sanitary significance of fecal coliforms in the environment. Washington DC: Federal Water Pollut Contr Admin Publication WP-20-3; 1966.

5. Rawat M, Jakher GR. Evaluation of bacterial indicators for assessment of faecal pollution of a fresh water body of Thar desert of Rajasthan, India, with respect to water quality. J Aqua Bio 2007;22:1-12.

6. Leclere HD, Mossal AA, Edberg SC, Struijk CB. Advances in the bacteriology of the coliform group; their suitability as mark- ers of microbiological water safety. Ann Rev Microbiol 2001;55:201-34.

7. Golterman HL, Clymo RS, Ohnstad MA Methods for physical and chemical analysis of freshwater. 2nd ed. IBP and handbook no. 8. London: Blackwell Scientific Publications; 1978. 213 pp .

8. Bonde GJ. Bacterial indicator water pollution. In: Droop MR, Januascn HW. Advances in aquatic in microbiology. London and New York: Academic Press; 1977. pp 273-364.

9. APHA-AWWA-WPCF. Standard methods for examination of water and wastewater. Washington DC: American Public Health Association 14th ed; 1975. pp 769.

10. Patralekh LN. Bacterial density in the Ganges at Bhagalpur, Bihar. J Ecobiol 1991;3:102-5.

11. Kothandaraman V, Thergaonkar VP, Koshy
T, Ganapathi SV. Physico-chemical and biological aspects of Ahmedabad sewage. Envoron Health 1953;5:356-63.

12. Gupta BB, Kumar S. Bacteriological quality of Aligarh waters. J Ecobiol 1991;3:1526.

13. Kabler PW, Clark HF. Coliform group and faecal coliform organisms as indicators of pollution in drinking water. $\mathrm{J}$ Am Water Works Assoc 1960:1577.

14. Strickland JDH, Parsons TR. A practical hand book of seawater analysis. Ottawa: Fisheries Research Board of Canada 167 ed; 1972. p 310.

15. Thienemann AF. Untersuchungen über de Beziehung zwischen dem Sauerstoffgehalt des Wassers und der Zusammensetzung der Fauna in norddeutschen Seen. Schweizerbart; 1918. pp 1-65. 